\title{
AN ANALYSIS OF THE DETERMINANTS OF PADDY AND PULSE DEVELOPMENT IN PAPUA PROVINCE
}

\author{
${ }^{1}$ Demas Wamaerand ${ }^{2}$ Kuntoro Boga Andri \\ ${ }^{1}$ Balai Pengkajian Teknologi Pertanian (BPTP) Maluku, Ambon \\ ${ }^{2}$ Loka Pengkajian Teknologi Pertanian (LPTP) Sulawesi Barat \\ E-mail: kuntoro@gmail.com; wamaerdemas@yahoo.com
}

\begin{abstract}
Abstrak : Penelitian ini bertujuan untuk: (1) memetakan pola distribusi penerapan inovasi teknologi pertanian spesifik lokasi,(2) mengetahui faktor penentu keberhasilan distribusi penerapan inovasi teknologi pertanian spesifik lokasi, (3) perbaikan pola distribusi dan percepatan adopsi dan difusi inovasi teknologi mendukung usaha agribisnis dan agroindustri padi, ubi jalar dan kedelai di Papua. Kegiatan penelitian dilakukan selama Maret 2011 sampai dengan Februari 2014 dengan menggunakan 3 pendekatan (metode) yaitu (1) Desk Studi terhadap SL-PTT padi, kedelai dan ubi jalar (2) Survei untuk memperoleh data kuantitatif di 3 kabupaten terpilih dengan memilih secara purposive 10-20 responden, (3) aplikasi pola difusi melalui demonstrasi bibit unggul padi, jagung dan kedelai di satu BPP atau satu petani penangkar benih sumber di 3 kabupaten terpilih. Data agronomis ditabulasi dan dianalisis secara deskriptif. Analisis tingkat efisiensi penerapan teknologi dalam demplot digunakan indikator imbangan penerimaan dan biaya atau analisis $R / C$ ratio. Untuk mengukur keberhasilan penerapan inovasi teknologi di dalam demplot perlu ditetapkan indikator kinerja, meliputi aspek penggunaan input, proses, output, outcome, benefit dan dampak. Hasil kajian menunjukkan bahwa penyebaran inovasi teknologi pertanian spesifik lokasi untuk pengembangan komoditas padi, jagung, kedelai dan ubi jalar, sudah menyebar disebagian besar wilayah sentra pengembangan pertanian tanaman pangan di Papua. Akan tetapi hanya terkonsentrasi di sekitar areal pemukiman transmigrasi. Varietas baru benih unggul tanaman kedelai dan padi, menunjukkan produktivitas yang lebih baik dibanding varietas lama yang sudah berulang-ulang ditanam petani. Varietas unggul jagung yang diintroduksi kurang berkembang karena masih terkendala dengan pemasaran, jika pasar sudah tersedia, maka petani bersedia mengembangkannya.
\end{abstract}

Kata Kunci: inovasi, distribusi, difusi, teknologi pertanian, Papua

Abstract: This study aims to: (1) mapping the distribution pattern of the application of
agricultural technology innovation specific locations, (2) determine the critical success
factors distribution application of agricultural technology innovation specific
locations, (3) improvement of distribution patterns and acceleration of the adoption
and diffusion of technological innovations to support agribusiness and agroindustrial
rice, sweet potatoes and soybeans in Papua. The research activities carried out during
March 2011 to February 2014 using three approaches (methods), namely (1) Desk
Study on the SL- PTT rice, soybean and sweet potato (2) surveys to obtain
quantitative data in three districts purposively selected with 10- 20 respondents, (3)
the application pattern of diffusion through the demonstration of quality seeds of rice,
corn and soybeans in the BPP or a farmer seed sources in three selected districts.
Agronomic data were tabulated and analyzed descriptively. Analysis of the level of
efficiency in the application of technology used indicator plots the balance receipts
and fees or analysis of R / C ratio. To measure the success of the application of
technological innovations in the plots need to set performance indicators, covering 
aspects of the use of inputs, processes, outputs, outcomes, benefits and impacts. The results show that the dissemination of technological innovations for the development of location-specific agricultural commodities of rice, corn, soybean and sweet potato, has spread in most regions crop farming development centers in Papua. But only concentrated around the transmigration settlement area. New varieties of soybean plants yielding seeds and rice showed better productivity than the old varieties that have been repeatedly planted by farmers. Yielding varieties of maize is being introduced less developed because it is still constrained by marketing, if the market is readily available, farmers are willing to develop it.

Keywords: innovation, distribution, diffusion, agricultural technology, Papua

\section{BACKGROUND OF THE STUDY}

One of the keys to success for the acceleration of agricultural development with the priority of food security are accelerating dissemination begun all location-specific agricultural technology innovation in a region with a particular distribution pattern for the application of agricultural technology innovation. Where food security can be achieved if farmers adopt recommended technology that can improve agricultural production, income and welfare. It can be created, if the acceleration dissemination approach used, in accordance with the socioeconomic and cultural conditions of the target. In addition, a new paradigm for development requires that the role of research dissemination activities has become just as important as research and assessment activities.

Targets generally be achieved dissemination can be learned from the "spread" of information technology to users of the technology to be "available" a concrete example of the application of technology in the field (Hendayana, 2007). Therefore, the purpose of dissemination is more emphasis on improving the ability of the quality adoption of agricultural innovation results of research and assessment through various communication activities, promotion, commercialization and deployment package superior technology required and generate added value for the various audiences of users and the organization of dissemination material counseling, either in print or through electronic media (Padmowihardjo, 2002; Suradisastra, 2005). Which can be supported by traditional leaders, religious leaders, and community site development.
Evaluation results show the success of some regions in implementing technological innovation with dissemination methods designed through SL-PTT (Field School-Crop Management and Integrated Resource) program innovation PTT paddy and soybeans and corn. Thus, innovation PTT is rated as one of the models of dissemination of agricultural innovations that can increase agricultural productivity and farmers' welfare. However the implementation of PTT innovation in multiple locations, including locations PTT paddy, soybeans and sweet potatoes in Papua, has not succeeded in increasing the productivity of farmers in the area. Which raised the question of what factors cause the lack of success?

According Syahyuti (2007), the program generally more emphasis on process (empowerment) than goals to be achieved. In an effort to empower not thought patterns and determinants distribution of the application of innovation in each location, where the program has successfully achieved the goal of farmers in some locations while others have not.

Besides general dissemination activities carried out in the neighborhood, especially the Ministry of Agriculture Agricultural Research Agency, as the title of technological, application of technology, information retrieval, open-field, business meetings, and others. Such dissemination has also been successful in increasing the productivity of agricultural yields in some areas outside Papua or specific communities in Papua. Thereby allegedly causing several unsuccessful applications of innovation and dissemination activities of the other, yet precisely due to the application of the distribution pattern of dissemination used and also not knowing the deciding factor will be the tipping point 
application of innovation in a region or a community of farmers. Therefore, it is necessary to obtain a study mapping the distribution pattern of dissemination of appropriate innovations for farmers in Papua to accelerating the adoption of location-specific agricultural technology innovation.

For the province of Papua to date rate of adoption of innovations by the farm community is still low, therefore it is expected that the acceleration of the adoption of innovations, in order to improve food security, particularly an increase in agricultural productivity based on science and technology (Science and Technology). Because it has been available agricultural innovation of science and technology based on the level of research institutions, both research institutions and universities. The resulting technological innovation, research institutions such as the Agency for Agricultural Research for some food crops, including paddy and pulses seeds. Paddy seeds (Inpari 1-9, Inpara, Cigeulis, ciherang, etc.) Can increase paddy productivity 4-7 ton / ha, sweet potato (Solossa Papua, Papua Pattipi, Sawentar, Ayamurasaki, and others) can improve the productivity of sweet potato in Papua up to 25 tons / ha, and soybean (Anjasmoro, Kaba, and Tanggamus) production may reach 1-2 ton / ha.

All of these innovations have been disseminated, but the technology has not yet fully implemented disseminated farmers, so there is still a difference between the productivity of agricultural research and productivity at the farm level. Productivity at farm level can be improved, if farmers adopt agricultural technology innovation. Therefore, it is necessary to approach the appropriate dissemination models created by accelerating the dissemination of innovation.

According to the Department of Agriculture and Food Security Papua (2008) and also Malik and Hendayana (2005), in the development of the paddy plant, paddy seed is still a problem, because of the unavailability of seeds of new varieties of paddy quality in each center for paddy development in Papua. And until now BBI paddy in Kurik Merauke only able to provide a seed source (FS) whose capacity is only able to meet less than 200 tonnes, while BBU, BBP and breeders, could only be able to produce seedlings for distribution of approximately 400 tons were only able to meet demand seeds to 19997 ha of the 25,200 ha of paddy fields of raw scattered some rice production centers in Papua. This will certainly affect paddy production to meet the demand for rice increases with population growth.

To be able to help support the main target The Ministry of Agriculture according Year Strategic Plan 2010 - 2014, such as selfsufficient and sustainable food self-sufficiency, then the efforts to improve the capacity and performance of institutional seed needs to be done, so that rice production could be increased. The repair can be done by empowering institutions, both formal institutional seed (BBI, BBU, BBP) and breeders in every area of development centers. For that to know the pattern of implementation and application of innovation determinants distribution of improved seed paddy in the area concerned.

Here paddy likely to be developed based agribusiness and agro-industry, because since 2010, the SL-PTT (Field School-Crop Management and Integrated Resource) paddy will be implemented in approximately seven districts in the province of Papua, which includes: Merauke, Jayapura, Sarmi, Jayawijaya, Nabire, Keerom and the city of Jayapura. With an area that will be developed covering an area of 17,500 ha, an area which will be accompanied by the SL-PTT approach covering 25 ha, and laboratory field (LL) 1 ha. Superior new varieties (VUB) paddy developed among other types of Inpari, Inpara, local superior species, and others. This would require paddy seed, especially seed spread as much as 350 tons (if need paddy seed $20 \mathrm{~kg} / \mathrm{ha}$ ), in order to meet the area to be developed.

In the development of paddy, paddy seed is a crucial issue in Papua, due to efforts to increase rice production, which is currently being promoted through SL-PTT government is largely determined by the quality of paddy seeds to be used. Moreover, not all new varieties of paddy produced IAARD known by farmers, whereas those varieties have the potential, good production, flavor and resistance to pests and diseases as well as shortlived. There are still many farmers do not use seed varieties labeled due to, among others, the 
availability of seedlings for distribution (ES) at the field level is still limited.

Agricultural extension agencies, especially BPP (Institute of Agricultural Extension) as the spearhead of the transfer of agricultural technology to farmers are strategic partner of the Ministry of Agriculture, which is generally located at the district level. According to Sinar Tani Development Foundation (2001) and also Sudaryanto and Pranadji (2006), need to be built close cooperative relationship and continuous (partnership) between research institutes and extension services, as this will be the foundation for the development of agriculture. Thus the need to create partnerships with educational institutions, so that the acceleration of technology innovation dissemination of research results to farmers the user can be improved.

The objectives of this study were (1) to map the distribution pattern of the application of agricultural technology innovation specific to the commodity paddy, yams and soy, (2) determine the critical success factors distribution of the application of agricultural innovations specific to PTT paddy, yams and soy, (3 ) improvement of distribution patterns and acceleration of the adoption and diffusion of technological innovations to support agribusiness and agro-paddy, sweet potatoes and soybeans in Papua, which is in line with the strategic program of the Ministry of Agriculture, in order to achieve food security through diversification.

\section{METHODOLOGY}

The study conducted during the period of March 2011 to February 2014. The study activities using three approaches (methods), namely (1) Desk study, this approach is used to obtain data on the spread of technological innovation PTT paddy, soybean and sweet potato in 3 districts (Jayapura Regency, Keerom and Kota Jayapura), (2) survey techniques a case study to obtain quantitative data on the 3 districts purposively selected with 10-20 respondents selected locations in each sub-district/village regarding the success and several unsuccessful implementation of innovations that have been disseminated BPTP Papua and (3) the application pattern of diffusion through the demonstration of seeds superior paddy, corn and soybeans in the BPP or a farmer seed sources in 3 selected districts.

To approach the 3rd, implementation diffusion mechanism implemented by the method of demonstration plots. For the implementation of dissemination selection and location of study intentionally the tribes Papuans and migrants' communities in Keerom, Jayapura and Jayapura City. Samples village within the indigenous tribe or transmigration sites chosen by 3 villages, using two approaches, namely (1) farmer group union (Gapoktan) and (2) individual farmers in 3 WKBPP or 1 WKBPP at each selected location (district/city), Plots with an area of each commodity for the farmer groups 1 ha and breeder farmers under the conditions of farmers. Plan implementation of demonstration plots in farmer groups/farmer breeder adapted to the local growing season.

The charge will be disseminated technological innovations are the result of the assessment technology package paddy system, yams and soybeans that have been produced at that location.

Paddy: seeds (Inpari 1-9, Cigeulis, Ciherang), the cropping pattern legowo 2: 1, fertilization with the recommended dose, the eradication of pests / diseases, weed control with the hedgehog, timely harvest.

Sweet Potato: some local clones lowlands; perfect land management; planting sweet potato with Kuming system (the way farmers) measuring 3 meters $x 10$ meters with a spacing of $75 \mathrm{~cm} \mathrm{x} 100 \mathrm{~cm}$; organic fertilizer with a dose of 20 tonnes / ha; with productivity ranging from 24-25 tonnes / ha (Simanjuntak et al, 2002; Soplanit et al, 2005).

Soybeans: the use of seeds (Anjasmoro, Kaba and Grobogan), planting with spacing as recommended, the recommended dosage of fertilization, weed control, timely harvest.

Using the approach demonstration plots or Dembul at a location close to the farmers. Based on the principles of effectiveness, efficiency, flexibility, benefits, equity and sustainability.

Agronomic data were tabulated and analyzed descriptively. Analysis of the level of efficiency in the application of technology used indicator plots balance receipts and expenses or analysis of the $\mathrm{R} / \mathrm{C}$ ratio. To measure the 
success of the application of technological innovations in the plots needs to be established performance indicators, covering aspects of the use of inputs, processes, outputs, outcomes, benefits and impacts. The indicators include: (1) The pilot project approach, able to encourage the adoption of location-specific agricultural innovation; (2) The cooperator farmers to adopt the technology applied; (3) non cooperator farmers interested in innovation exhibited in the demonstration plot (4) growing adopter in the vicinity of the next planting season, (5) BPP interested in the innovations offered in the pilot project and would cooperate with the Ministry of Agriculture in developing technological innovations that have been adopted by farmers ,

To bring research results to farmers through demonstration plots at BPP or farmer group chairman, the diffusion mechanism chosen was the model of technology transfer which can be obtained feedback (Figure 1).

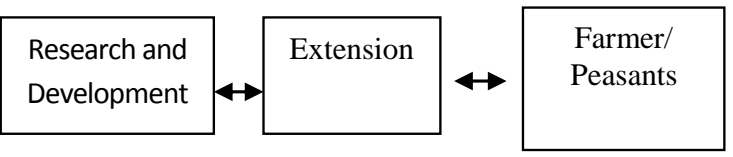

Figure 1 . The feedback technology transfer modelSource: Kurnia, 2000

With the hypothesis that innovations are the source close to the farmer and according to the needs of farmers, farmers receive will be faster, more quickly obtained feedback, and sooner visible performance against the farmers' adoption of technological innovation and disseminated.

\section{RESULTS AND DISCUSSIONS}

\section{Implementation of Specific Location Agricultural Innovation}

For agricultural innovation concerning commodities as paddy, soybean and sweet potato propagated by BPTP Papua over the last 5 years, at three selected locations can be seen in Table 1.

Table 1. Distribution of R \& D Technological Innovation in three selected districts

\begin{tabular}{|c|c|c|c|c|c|}
\hline \multirow[t]{2}{*}{ No } & \multirow{2}{*}{$\begin{array}{l}\text { Innovation } \\
\text { Type }\end{array}$} & \multicolumn{3}{|c|}{ Location } & \multirow[t]{2}{*}{ Description } \\
\hline & & Jayapura city & Keerom & Jayapura & \\
\hline 1. & $\begin{array}{l}\text { Paddy } \\
\text { Varieties }\end{array}$ & $\begin{array}{c}\text { Ciherang, Cigeulis, } \\
\text { Mekongga, Inpari } \\
\text { 7, Inpari 9, IR61 }\end{array}$ & $\begin{array}{l}\text { Ciherang, Cigeulis, } \\
\text { Inpari } 7, \text { Inpari } 9\end{array}$ & $\begin{array}{l}\text { Ciherang, Inpari 7, } \\
\text { Inpari 9, IR64 }\end{array}$ & $\begin{array}{l}\text { Most still exist used } \\
\text { by farmers }\end{array}$ \\
\hline 2. & $\begin{array}{l}\text { Soybean } \\
\text { Varieties } \\
\text { prefetch } \\
\text { queue }\end{array}$ & $\begin{array}{c}\text { Anjasmoro, Ijen, } \\
\text { Lokon }\end{array}$ & $\begin{array}{l}\text { Anjasmoro, Lokon, } \\
\text { Galunggung, }\end{array}$ & $\begin{array}{l}\text { Anjasmoro, } \\
\text { Grobogan, Ijen, } \\
\text { Tanggamus }\end{array}$ & $\begin{array}{l}\text { Most still exist used } \\
\text { by farmers }\end{array}$ \\
\hline 3. & $\begin{array}{l}\text { Sweet potato } \\
\text { varieties }\end{array}$ & - & $\begin{array}{l}\text { Papua solosa, } \\
\text { Ayamurasaki, left- } \\
\text { handed, juice, beta-2, }\end{array}$ & $\begin{array}{l}\text { Solosa Papua, Papua } \\
\text { Patipi, Ayamurasaki, } \\
\text { left-handed, beta 2, } \\
\text { cider, }\end{array}$ & $\begin{array}{l}\text { Only a few are still } \\
\text { maintained as a lefty, } \\
\text { cider and } \\
\text { Ayamurasaki }\end{array}$ \\
\hline 4. & $\begin{array}{l}\text { Legowo } \\
\text { Paddy } \\
\text { Planting } \\
\text { Techniques }\end{array}$ & $\begin{array}{l}\text { Had already } \\
\text { introduced }\end{array}$ & $\begin{array}{l}\text { had already } \\
\text { introduced }\end{array}$ & $\begin{array}{l}\text { Had already } \\
\text { introduced }\end{array}$ & $\begin{array}{l}\text { Only a small } \\
\text { proportion } \\
\text { farmers using this } \\
\text { pattern }\end{array}$ \\
\hline 5. & $\begin{array}{l}\text { Maize } \\
\text { Varieties }\end{array}$ & $\begin{array}{l}\text { bisma, } \\
\text { srikandikuning, } \\
\text { lamuru }\end{array}$ & $\begin{array}{l}\text { bima 2, bisma, } \\
\text { srikandikuning }\end{array}$ & $\begin{array}{l}\text { bima 2, bisma, } \\
\text { srikandikuning, } \\
\text { lamuru }\end{array}$ & $\begin{array}{l}\text { Not spread } \\
\text { extensively, because } \\
\text { the price is less } \\
\text { competitive }\end{array}$ \\
\hline
\end{tabular}

Source: Field Survey, 2011-2014 


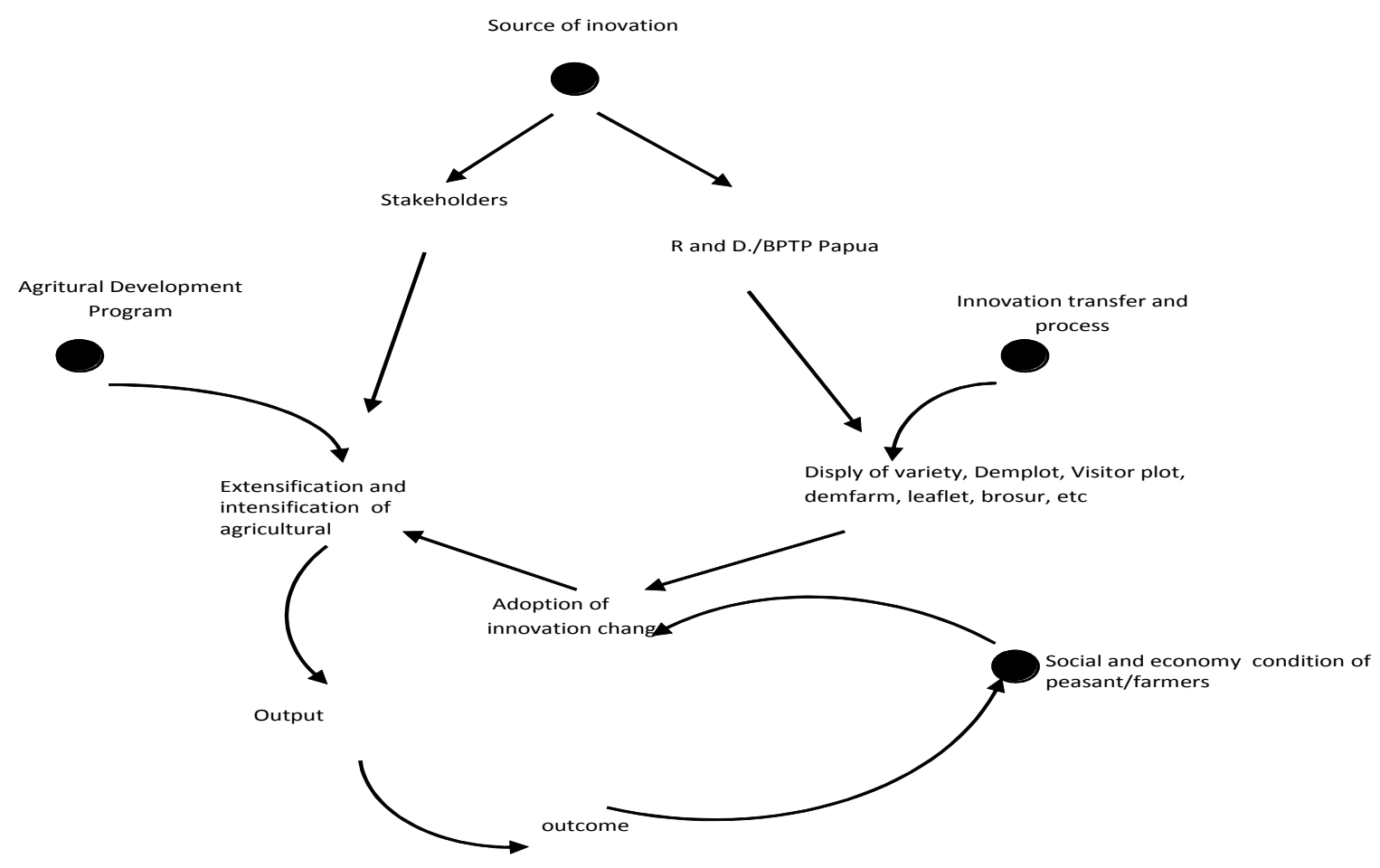

Figure 2.Distribution Pattern of Innovation Implementation

Distribution Patterns of Specific Location Agricultural Innovation

In general, there are three main components that play a role in the distribution patterns of agricultural innovation in the center of the development of paddy, soybeans, corn and sweet potatoes, namely 1) the institution assemblers Technology (BPTP Papua), the Department of Agriculture Regency/ Municipality, 3) the farmer and his family. The Diagram of innovative application distribution pattern is as shown in the figure below (Figure 2).

From Figure 2, a circular line defines the process of feedback, and straight lines define the distribution pattern of innovation. In the feedback process, when the production of innovation increases, income/ outcome increases. These conditions will encourage more widespread application of innovation selection, and so on.

The Distribution of Determinants of Agricultural Innovation Implementation Overall success factors specific application of agricultural innovations divided over two major parts, namely external and internal factors. External factors ie factors or conditions that are outside the control of peasants and family farmers, while the internal factors that are factors inherent to the characteristics of peasants or family farmers.

\section{Paddy farming}

Some external determinants that can be studied in the management of paddy plants include: the process of delivering innovation, intensity of counseling, and marketing and product prices of rice.

The process of delivering innovation is a pattern or approaches used to deliver innovation to the user/farmer. An example is the study (display) the various varieties of paddy plants in farmers' fields in the form of demonstration plots yielding varieties. Here institution that plays an important role of technical agencies that include the Agricultural office (Dinas) of Jayapura, extension agency and and BPTP.

For determining factors such as the intensity and effectiveness of counseling conducted PPL as agent reformer. If viewed from the side of the opening of the region, then the intensity of counseling visits to be better than the previous state (before the expansion area). But the effectiveness of counseling, 
according to the extension is less effective, because the material extension information available at the BPP, has not been entirely transferred to the farmer, due to lack of development costs. Therefore, if it could be programmed with either of the extension system, the distribution of the application of this innovation can run better.

Marketing and prices, as other determining factors that will determine the distribution of innovation implementation, in general, the market is still a problem for paddy, due to low prices at harvest time. For that we need a system that can guarantee the stability of the price of rice.

The internal determining factors can include the socio-economic readiness of farmers and their families in the adoption of innovations. Social readiness is related to the ability of family labor (quantity), skill / skills in the application of innovation and mindset (insight) farmers in translating the prospects of innovations introduced. Economically, associated with the financial capacities (capital resources) are owned by farmers. The more expensive an innovation, the lower the farmer's response to these innovations.

\section{Corn and Soybeans farming}

Here, the dominant factor is the price and marketing. The specific conditions of corn and soybeans are low selling prices and relatively high price fluctuations. Field assessment and interviews with farmers give an overview that farmer as producers have a very weak bargaining power price as a result of the inclusion of corn and soybean products from other provinces.

\section{Sweet potato farming}

So far, sweet potato productivity at farm level is still low. The low productivity due to package technology is not yet widely known and low adoption level of technology by farmers (Malik and Wamaer, 2010). Technical factors (seeds, fertilizer and cultivation) will determine the productivity of sweet potato. In order that the innovation of yams can be rapidly adopted by farmers, it is need the dissemination through pilot project or demonstration plots. The higher adoption of innovation of yams cultivation technology, the higher productivity of yams can be increased.
Improvement of distribution patterns and acceleration of the adoption and diffusion of innovation

To improve the distribution patterns and acceleration of innovation adoption, the approach used in this study dembul (demonstration of improved seed), with a view to accelerate the adoption of innovation.

\section{Demonstration of Superior Soybean Seed}

Farmer cooperators were chosen to carry out an assessment to transmigration farmers in Keerom location (Arso 1). Soybean cultivation observation for new type varieties is 2 ha under 2 farmer cooperators land. The local varity normally usage by farmer considered as control. In this studied area soybean cultivation are sufficiently developed. As well as a pretty good price factor is the reason for farmers to cultivate soybean this seasson. For that matter, a good market is expected to support the accelerated adoption of agricultural innovations specific to soybeans.

Results from soybean varieties were introduced to farmers through dembul showed Kaba varietiy have a higher productivity than the other two varietiesy, also higher than the varieties that have often usage in the studied location (control). The local varieties observed as control for distinguishes it from the introduced varieties.

\section{Demonstration of Superior Paddy New Variety}

From the display of varieties carried out through activities of SLPTT in 2010, farmers quite interested in the varieties of Inpari7 which has been demonstrated, because the result is higher and more resistant to brown plant hopper pest, and pest fake white. For that Inpari 7 has been tested in the form Dembul, with the average number of seeds / panicle, weight of 1000 seeds, grain hollow\%, and production / ha 4 VUB Inpari presented in Table 3.

In Table 3, it appears that the average number of seeds / panicle and production per hectare VUB Inpari 7 significantly different from the control, but the weight of 1000 seeds and empty grain were not significantly different. 
Demas W., Kuntoro B.A. : An Analysis Of The Determinants Of Paddy ....

Table 2. Performance of Production Dembul 3 soybean varieties in SanggariaArso Village, at 2011

\begin{tabular}{llcccc}
\hline No. & Varieties & $\begin{array}{c}\text { Production } \\
\text { Potential } \\
\text { (ton / ha) }\end{array}$ & $\begin{array}{c}\text { Production }(\mathrm{kg}) \\
(0.25 \mathrm{ha})\end{array}$ & $\begin{array}{c}\text { Productivity } \\
\text { (ton / ha) }\end{array}$ & $\begin{array}{c}\text { Seed Grade (BS / } \\
\text { FS / SS / ES) }\end{array}$ \\
\hline 1. & Anjasmoro & 2.2 & 375 & 1.50 & $\mathrm{SS}$ \\
2. & Kaba & 2.6 & 450 & 1.80 & $\mathrm{SS}$ \\
3. & Grobokan & 2.4 & 380 & 1.52 & $\mathrm{SS}$ \\
4. & Local (control) & 1.76 & 320 & 1.28 & - \\
\hline
\end{tabular}

Source: Field trial, 2011

Table 3. Average Number of Seeds / Tassel, Weight 1000 Seeds, \% Grain Marijuana, and Production / Ha Dembul Varieties Inpari7 in Koya West at 2011

\begin{tabular}{llcccc}
\hline No. & \multicolumn{1}{c}{ Variety } & $\begin{array}{c}\text { Seeds / } \\
\text { panicle }\end{array}$ & $\begin{array}{c}\text { Weight of 1000 } \\
\text { seeds }\end{array}$ & $\begin{array}{c}\text { \% Grain } \\
\text { hollow }\end{array}$ & Production (t / ha) \\
\hline 1 & Inpari 7 & 133.5 & $26.5^{\mathrm{tn}}$ & $5.1^{\mathrm{n}}$ & $6.2^{\mathrm{n}}$ \\
2 & Ciherang (control) & 110.3 & 26.0 & 4.6 & 4.2 \\
\hline
\end{tabular}

Note: Test - $\mathrm{t}$ (treatment vs. control) at the 0.05 level.tn $=$ unreal, $\mathrm{n}=$ real

Source: Field trial, 2011

The number of seeds / panicle at VUB Inpari7 as many as 133.5 seeds, while farmers pattern just 110.3 seeds. The production of dry milled grain (GKG) at new type variety of Inpari 7 gained $6.2 \mathrm{t} /$ ha and the control only $4.2 \mathrm{t} / \mathrm{ha}$.

The production difference between the varities are $2.0 \mathrm{t} / \mathrm{ha}$. The high production obtained in new type variety of Inpari 7 due to the pattern of implementation of integrated pest management and paddy cultivation technology elements accordingly. While for the control, that they did not not carried out fully the package of technology, so that its productivity is lower anyway.

\section{CONCLUSIONS AND CONSIDERATIONS}

Dissemination of technological innovations in the development of location-specific agricultural commodities of paddy, corn, soybean and sweet potato based desk study have spread in most regions crop farming development centers in Papua. However the development of these commodities are underdeveloped, and only develops around the area of transmigration settlements.

Tthe introduced of new type varieties of improved soybean seed and paddy showed better productivity than the varieties that have been repeatedly and traditionally usege by farmers. The farmer's interest to innovate the new varitey need to be followed up with the provision of seeds, because of the availability of improved seed have been often not available when needed.

Yielding varieties of maize were introduced less developed because it is still constrained by marketing, if the market is readily available, the farmers want to develop it. Availability of the corn market could be facilitated by the local government to give stimulants to agribusiness entrepreneurs to develop the animal feed industry requires raw materials of corn.

Indispensable assistance through demonstration plots which have been socialized to farmers. To need the support of the relevant technical agencies (Bapeluh), so that improved seed which has been introduced can be developed to improve the productivity of paddy plants, soybeans and sweet potatoes.

\section{BIBLIOGRAPHY}

Deptan. 2008. Peraturan Minister of Agriculture No. 20 / PERMENTAN / TU.200 / 3/2008 on General Guidelines Proposal Preparation and Evaluation of Research and Technological Development. Jakarta.

Distan Papua. 2008. Breeding of Seed Potatoes Event Winning Local Department of Agriculture and Horticulture Papua 
Province. Download on the Website Government of Papua.

2009. The Grand Design Development of Food Crops and Horticulture 2009 - 2012. Cooperation Department of Agriculture and Horticulture Papua and Papua Institute for Agricultural Technology.

Hendayana, R. 2007. The track and Roadmap (Roadmap) Dissemination of Agricultural Technology Towards a Progressive Farmer. Proceedings of the National Workshop on Dissemination Innovation Accelerating Agricultural Technology Support the development Starting from the village.

Kurnia, G. 2000. Linkage Research and Extension in Agricultural Innovation Deployment Perspective. Proceedings of the National Workshop, Dissemination of Agricultural Innovation Era of Regional Autonomy, p. 19-24. Library and Technology Dissemination Center of Agriculture, Agricultural Research and Development Agency, the Department of Agriculture.

Padmowihardjo, S. 2002. Evaluation of Education. Open University, Jakarta.

Simanjuntak, Y., F. Wally, A. Soplanit, and D. Wamaer. 2002. Adaptation Test of Sweet Potato Varieties in Highlands Jayawijaya. Proceedings of the Regional Seminar. Research and Socio-Economic Development of Agriculture. Bogor.

Soplanit, A., D. Wamaer, and S. Tirajoh. 2005. Assessment of Organic Fertilization and Plant Spacing On Sweet Potato Crop Jayawijaya Highlands Province of Papua. Pusan Socio-Economic and Agricultural Policy and BPTP Bali. Proceedings of the National Seminar, Denpasar 28 September 2005.

Sihombing, S.R.D., D. Wamaer, A. Malik and M. Ondikeleu. 2009. Design Media and Methods to Accelerate Adoption of innovation technologies in increased production of sweet potato in Papua. Paper presented in the Seminar Evaluation Sinta 2009 in Hall IAARD Jakarta, December 8 to 9, 2009.

Sudaryanto, T. and Tri Pranadji. 2006. Transforming Institutions to Accelerate Adoption of Agricultural Technology Innovation in Papua Society. Proceedings Semnas BPTP Papua, Jayapura 24 to 25 July, 2006.

Suradisastra, K. 2005. Application Methods of Communication and Education in Technology Innovation Dissemination. Agency for Agricultural Research and Development. Jakarta.

Syahyuti. 2007. Application of Empowerment Approaches in Agricultural Development Activity: Activity Comparison P4K, PIDRA, P4MI and Prima Tani. Agro Economic Research Forum, Volume 25, No.2, December 2007: 104-116.

Simanjuntak, Y., F. Wally, A. Soplanit, and D. Wamaer. 2002. Adaptation Test of Sweet Potato Varieties in Highlands Jayawijaya. Proceedings of the Regional Seminar. Research and Socio-Economic Development of Agriculture. Bogor

Wally, F., Y. Simanjuntak, A. Soplanit, and Hendrik K. 1998. Study of Potato Farming Systems in Dryland Areas Agroekosistem Highlands Regional Seminar Proceedings. Research and Socio-Economic Development of Agriculture. Bogor.

Widyastuti, CA 2000. Knowledge Women About Sweet Potatoes and Contribution to Sustainability Diversity Sweet Potato Baliem Valley. A case study in the village of Waga-Waga, District Kurulu, Jayawijaya, Irian Jaya. Thesis, Graduate Program of Bogor Agricultural University. Unpublished.

Yayasan Pengembangan Sinar Tani. 2001. Agricultural Extension, Agricultural Extension Methods Sub Chapter, p. 278331. 